\title{
Frequency of acute stress disorder in health care workers of a tertiary level pediatric hospital during the National Safe Distance Strategy for COVID-19 prevention
}

\author{
Gina del C. Chapa-Koloffon ${ }^{1 *}$, María G. Jean-Tron ${ }^{1}$, Aidee V. Ávila-Hernández"1, \\ Horacio Márquez-González ${ }^{1}$, and Juan Garduño-Espinosa² \\ ${ }^{1}$ Departamento de Investigación Clínica; ${ }^{2}$ Dirección de Investigación. Hospital Infantil de México Federico Gómez, Mexico City, Mexico
}

\begin{abstract}
Background: Acute stress disorder (ASD) is one of the most frequent mental illnesses occurring during sanitary emergencies. This study aimed to estimate the frequency of ASD in health care workers of a tertiary level pediatric hospital during the coronavirus disease (COVID-19) pandemic. Methods: We conducted a cross-sectional study in which health care workers completed a virtual questionnaire, including sociodemographic information and the ASD scale. Results: We analyzed 206 questionnaires. The population was divided into three groups: attending physicians, medical residents, and nursing personnel. The frequency of health care workers who showed at least nine symptoms of ASD was $88.8 \%$. No significant differences were found between the studied groups. Conclusions: ASD is a frequent condition in health care workers in the context of the COVID-19 pandemic. We need to investigate further and assess risk and protective factors for developing this and other psychopathologies in this population.
\end{abstract}

Key words: COVID-19. Acute stress disorder. Pandemic. Health care workers.

\section{Frecuencia de trastorno por estrés agudo en el personal de salud de un hospital pediátrico de tercer nivel durante la Jornada Nacional de Sana Distancia para la prevención de la COVID-19}

\section{Resumen}

Introducción: El trastorno por estrés agudo es una de las enfermedades mentales más frecuentemente manifestadas en emergencias sanitarias. El objetivo de este estudio fue conocer la frecuencia con la que se presentó el trastorno por estrés agudo en el personal de salud de un hospital pediátrico de tercer nivel durante la epidemia de COVID-19. Método: Se realizó un estudio transversal en el que trabajadores de la salud contestaron un cuestionario virtual que incluyó datos sociodemográficos y la Escala de Trastorno por Estrés Agudo. Resultados: Se analizaron 206 encuestas. La población se dividió en tres grupos: médicos adscritos, residentes y personal de enfermería. El $88.8 \%$ de los trabajadores de la salud reportaron más de nueve síntomas de trastorno por estrés agudo. No se encontraron diferencias significativas entre los grupos de estudio. Conclusiones: Los síntomas del trastorno por estrés agudo son frecuentes en los trabajadores de la salud en el contexto de la COVID-19. Es necesario investigar acerca de los factores de riesgo y protectores asociados al desarrollo de esta y otras psicopatologías en dicha población.

Palabras clave: COVID-19. Trastorno por estrés agudo. Pandemia. Trabajadores de la salud.

\section{Correspondence:}

*Gina del Carmen Chapa Koloffon

E-mail: ginachapak@gmail.com
Date of reception: 21-07-2020

Date of acceptance: 14-08-2020

DOI: 10.24875/BMHIM.20000226
Available online: $24-02-2021$ Bol Med Hosp Infant Mex. 2021;78(1):10-17 www.bmhim.com 1665-1146/C 2020 Hospital Infantil de México Federico Gómez. Published by Permanyer. This is an open access article under the CC BY-NC-ND license (http://creativecommons.org/licenses/by-nc-nd/4.0/). 


\section{Introduction}

Coronavirus disease (COVID-19) is a respiratory illness caused by severe acute respiratory syndrome coronavirus $2^{1}$. It is airborne and characterized by shortness of breath, fever, muscle pain, and dry cough? The World Health Organization declared the "pandemic" status in March 20203.

On March 29, Mexican authorities announced implementing a hospital conversion model to coordinate and integrate hospitals' response to the care of severe patients with COVID-19. The Hospital Infantil de México Federico Gómez would initially be the national health institute that would care for pediatric patients $<18$ years of age with severe COVID-194.

In epidemics, mental health is often affected. Some common reactions include being afraid of getting sick or dying, having a beloved one who could be ill or die, uncertainty about the economic situation, boredom, loneliness, depression due to isolation, and the risk of physical or mental health deterioration in vulnerable people ${ }^{5}$.

When facing an unknown and potentially dangerous situation, it is normal to experience anxiety and decreased mood. The expectation is that these symptoms will not cause significant dysfunction and will improve. However, some people may develop more complex disorders and feel stressed, even when they are no longer in danger. In health emergencies, acute stress disorder (ASD) frequently occurs ${ }^{5}$. The following are the diagnostic criteria for this disorder:

a. Exposure to death, serious injury, or sexual violence, whether actual or threatened, in one (or more) of the following:

- Direct experience of the traumatic event(s)

- Direct presence of the event(s) experienced by others

- Learning that the traumatic event(s) has occurred to a close family member or friend

- Repeated or extreme exposure to aversive details of the traumatic event(s) (e.g., rescue workers collecting human remains; police officers repeatedly exposed to elements of child abuse).

b. Presence of nine or more of the symptoms from one of the five categories: intrusion, negative mood, dissociation, avoidance, and alertness, which begin or worsen after the traumatic event(s):

- Recurrence symptoms

1. Recurrent, involuntary, and distressing intrusive memories of the traumatic event(s)

2. Recurrent distressing dreams in which the content or difficulty sleeping is related to the event(s)
3. Dissociative reactions (e.g., flashbacks) in which the individual feels or acts as if the traumatic event(s) is recurring. These reactions can occur continuously, and the most extreme expression is a complete loss of awareness of present surroundings

4. Intense or prolonged psychological distress or significant physiological reactions in response to internal or external factors that symbolize or resemble an aspect of the traumatic event(s).

- Negative mood

1. Persistent inability to experience positive emotions (e.g., happiness, satisfaction, or loving feelings).

- Dissociative symptoms

1. Altered sense of the reality of self-surroundings or oneself (e.g., seeing oneself from another's perspective, being in a daze, and time slowing)

2. Inability to remember an essential aspect of the traumatic event(s) (typically due to dissociative amnesia, not to other factors such as head injury, alcohol, or drugs).

- Avoidance symptoms

1. Efforts to avoid distressing memories, thoughts, or feelings about or closely associated with the traumatic event(s)

2. Efforts to avoid external reminders (people, places, conversations, activities, objects, and situations) that arouse distressing memories, thoughts, or feelings about or closely associated with the traumatic event(s).

- Arousal symptoms

1. Sleep disturbance (e.g., difficulty falling or staying asleep, or restless sleep)

2. Irritable behavior and angry outbursts (with little or no provocation) typically expressed as verbal or physical aggression toward people or objects

3. Hypervigilance

4. Difficulty concentrating

5. Exaggerated startle response.

c. Duration of disturbance symptoms (in criterion B) ranges from 3 days to 1 month after trauma exposure

d. Disturbance causes clinically significant distress or impairment in social, occupational, or other important areas of functioning

e. Disturbances are not attributable to the physiological effects of substances (e.g., medication or alcohol) or other medical conditions (e.g., mild traumatic brain injury) and are not better explained by a brief psychotic disorder ${ }^{6}$.

In a review of the relationship between ASD and post-traumatic stress disorder (PTSD), it was concluded 
Table 1. Sociodemographic characteristics of health care workers by profession

\begin{tabular}{|c|c|c|c|}
\hline Sociodemographic characteristics & $\begin{array}{c}\text { Resident physicians }(\mathrm{n}=60) \\
\text { Frequency }(\%)\end{array}$ & $\begin{array}{c}\text { Attending physicians ( } \mathrm{n}=84 \text { ) } \\
\text { Frequency }(\%)\end{array}$ & $\begin{array}{c}\text { Nursing personnel ( } \mathrm{n}=62) \\
\text { Frequency }(\%)\end{array}$ \\
\hline $\begin{array}{l}\text { Gender } \\
\text { Female } \\
\text { Male } \\
\text { Age (mean } \pm \text { SD) }\end{array}$ & $\begin{array}{l}45(75) \\
15(25) \\
28.6 \pm 2\end{array}$ & $\begin{array}{c}53(63.1) \\
31(36.9) \\
39.9 \pm 10.2\end{array}$ & $\begin{array}{c}60(96.8) \\
2(3.2) \\
40.7 \pm 7.5\end{array}$ \\
\hline $\begin{array}{l}\text { Schooling } \\
\text { High school } \\
\text { Technical career } \\
\text { Bachelor's degree } \\
\text { Postgraduate }\end{array}$ & $\begin{array}{c}0 \\
0 \\
13(21.7) \\
47(78.3)\end{array}$ & $\begin{array}{c}0 \\
0 \\
0 \\
84(100)\end{array}$ & $\begin{array}{c}0 \\
4(6.4) \\
26(41.9) \\
32(51.6)\end{array}$ \\
\hline $\begin{array}{l}\text { Monthly income (MXN) } \\
\$ 4000 \text { a } \$ 8999 \\
\$ 9000 \text { a } \$ 29,999 \\
\$ 30,000 \text { a } \$ 44,999 \\
>\$ 45,000\end{array}$ & $\begin{array}{c}10(16.7) \\
50(84.3) \\
0 \\
0\end{array}$ & $\begin{array}{c}0 \\
25(29.8) \\
26(31) \\
33(39.4)\end{array}$ & $\begin{array}{c}23(37.1) \\
38(61.3) \\
1(1.6) \\
0\end{array}$ \\
\hline $\begin{array}{l}\text { Type of housing } \\
\text { Self-owned house } \\
\text { Self-owned apartment } \\
\text { Rented house } \\
\text { Rented apartment } \\
\text { Shared house/apartment } \\
\text { Loaned/rented room }\end{array}$ & $\begin{array}{c}5(8.3) \\
3(5) \\
0 \\
26(43.3) \\
20(33.3) \\
6(10)\end{array}$ & $\begin{array}{c}39(46.4) \\
11(13.1) \\
8(9.5) \\
17(20.2) \\
9(10.7) \\
0\end{array}$ & $\begin{array}{c}27(43.5) \\
20(32.3) \\
3(4.8) \\
4(6.5) \\
8(12.9) \\
0\end{array}$ \\
\hline
\end{tabular}

MXN: Mexican pesos; SD: standard deviation.

that $30-83 \%$ of people who were diagnosed with ASD subsequently developed PTSD?

The objective of this study was to examine the frequency of ASD symptoms in health-care personnel (resident physicians, attending physicians, and nursing personnel) who were in contact with COVID-19 patients during the pandemic in the Hospital Infantil de México Federico Gómez.

\section{Methods}

An observational, cross-sectional, prospective, and descriptive study was carried out employing a virtual questionnaire addressed to health-care personnel (resident physicians, attending physicians, and nursing personnel), which was distributed by email from April 23 to May 23, 2020. The questionnaire contained an informed consent form specifying that the information would be handled anonymously and confidentially. If at least nine symptoms of ASD were detected, an email address was solicited to provide information regarding treatment. The questionnaire was approximately 20 min long and consisted of multiple-choice questions in which sociodemographic factors were explored. The ASD scale is a screening test of 19 items scored on a Likert-type scale, which describes symptoms regarding the criteria of recurrence, avoidance, arousal, and dissociative cognitive alterations. This test was also applied in the same format. Based on the DSM-5 (Diagnostic and Statistical Manual of Mental Disorders) 7 , a cutoff point $\geq 27$ on criterion $B$ suggests a diagnosis of ASD. In contrast, a score $>56$ indicates that the person is at greater risk of $\mathrm{PTSD}^{8}$.

\section{Statistical analysis}

A descriptive analysis was carried out for both sociodemographic and outcome variables. For qualitative variables, frequencies and percentages were used; for quantitative variables, mean and standard deviation were used. Inferential statistics were carried out with the $\chi^{2}$ test to determine the differences in the outcome variables between groups.

\section{Results}

\section{Sociodemographic data}

We recruited 206 participants. The surveys were carried out from April 23 to May 23, mostly during the first 3 weeks of May 2020. 
Table 2. ASD scale results of health care workers by profession

\begin{tabular}{|c|c|c|c|c|}
\hline ASD scale & $\begin{array}{c}\text { Resident physicians }(\mathrm{n}=60) \\
\text { Frequency }(\%)\end{array}$ & $\begin{array}{c}\text { Attending physicians ( } \mathrm{n}=84 \text { ) } \\
\text { Frequency }(\%)\end{array}$ & $\begin{array}{c}\text { Nursing personnel }(n=62) \\
\text { Frequency }(\%)\end{array}$ & p-value \\
\hline No acute stress & $13(21.7)$ & $22(26.2)$ & $14(22.6)$ & \multirow[t]{3}{*}{0.96} \\
\hline Acute stress & $39(65)$ & $52(61.9)$ & $41(66.1)$ & \\
\hline Acute stress and risk of PTSD & $8(13.3)$ & 10 (11.9) & $7(11.3)$ & \\
\hline
\end{tabular}

ASD: Acute stress disorder; PTSD: Post-traumatic stress disorder.

${ }^{*} \mathrm{p}$-values calculated by $\chi^{2}$ test.

Table 3. Dissociative symptoms (ASD scale) by profession

\begin{tabular}{|c|c|c|c|c|}
\hline Item & $\begin{array}{c}\text { Resident physicians } \\
\text { (n=60) } \\
\text { Frequency (\%) }\end{array}$ & $\begin{array}{l}\text { Attending physicians } \\
\text { (n= 84) } \\
\text { Frequency (\%) }\end{array}$ & $\begin{array}{c}\text { Nursing personnel } \\
\qquad(\mathrm{n}=62) \\
\text { Frequency }(\%)\end{array}$ & p-value \\
\hline Emotional distress or detachment & $29(48.3)$ & $25(29.8)$ & $29(46.8)$ & 0.037 \\
\hline Being in a daze & $25(41.7)$ & $24(28.6)$ & $19(30.6)$ & 0.23 \\
\hline $\begin{array}{l}\text { Altered sense of the reality (like being in a } \\
\text { dream) }\end{array}$ & $12(20)$ & 15 (17.9) & $14(20.3)$ & 0.88 \\
\hline Distance from oneself (as an outside observer) & $8(13.3)$ & $7(8.3)$ & $11(17.7)$ & 0.23 \\
\hline Difficulty remembering things & $8(13.3)$ & $6(7.1)$ & $4(6.5)$ & 0.32 \\
\hline
\end{tabular}

ASD: Acute stress disorder.

${ }^{*} \mathrm{p}$-values calculated by $\chi^{2}$ test.

The population was divided into three groups: resident physicians, attending physicians, and nursing personnel. All participants were actively employed healthcare workers at the Hospital Infantil de México Federico Gómez. Sociodemographic characteristics of health care workers are described in Table 1.

\section{ASD scale results}

Based on criterion B, $88 \%$ of the total population obtained scores that met the criteria for the diagnosis of ASD, of which $13.6 \%$ obtained a score indicating a significant risk of eventually developing PTSD (Table 2).

\section{Scale results by type of symptoms}

The following section describes the scale results by a subset of symptoms: dissociation, recurrence, avoidance, and arousal. Although no significant differences were found between groups, some important data were observed. The most frequently reported symptom by attending physicians and nurses was the feeling of being more alert to danger (alertness) $(41.7 \%$ and
$54.8 \%$, respectively). In comparison, resident physicians' most frequent symptom was sleeping difficulty derived from anxiety (56.7\%). In addition, resident physicians were the group that most frequently presented symptoms of each of the subsets.

\section{Dissociative symptoms}

The most frequently reported dissociative symptom was emotional detachment. A statistically significant difference was found between groups. The percentage of resident physicians that reported emotional distress was $48.3 \%$, whereas $46.8 \%$ of the nursing personnel and $29.8 \%$ of attending physicians reported this symptom $(p=0.037)$ (Table 3$)$.

\section{Recurrence symptoms}

The most frequently reported symptom of recurrence in all groups was experiencing anxiety when recalling the event. Table 4 describes participants' frequency with positive answers for the items that assessed recurrence symptoms within the ASD scale. 
Table 4. Recurrence symptoms (ASD scale) by profession

\begin{tabular}{|c|c|c|c|c|}
\hline Item & $\begin{array}{c}\text { Resident physicians } \\
\text { (n= 60) } \\
\text { Frequency }(\%)\end{array}$ & $\begin{array}{l}\text { Attending physicians } \\
\qquad \begin{array}{c}(\mathrm{n}=\mathbf{8 4}) \\
\text { Frequency }(\%)\end{array}\end{array}$ & $\begin{array}{l}\text { Nursing personnel } \\
\qquad(\mathrm{n}=62) \\
\text { Frequency }(\%)\end{array}$ & p-value \\
\hline Intrusive memories and thoughts & $15(25)$ & $12(14.3)$ & $14(22.6)$ & 0.23 \\
\hline Distressing dreams or nightmares & $8(13.3)$ & $13(15.5)$ & $9(14.5)$ & 0.93 \\
\hline Feeling that the event can recur at any time & $14(23.3)$ & $16(19)$ & $13(21)$ & 0.82 \\
\hline $\begin{array}{l}\text { Feelings of distress on reminders of the } \\
\text { pandemic }\end{array}$ & $17(28.3)$ & $18(21.4)$ & 14 (22.6) & 0.6 \\
\hline
\end{tabular}

ASD: acute stress disorder.

*p-values calculated by $\chi^{2}$ test.

Table 5. Avoidance symptoms (ASD scale) by profession

\begin{tabular}{|l|c|c|c|c|}
\hline Item & $\begin{array}{c}\text { Resident physicians } \\
\mathbf{( n = 6 0 )} \\
\text { Frequency (\%) }\end{array}$ & $\begin{array}{c}\text { Attending physicians } \\
(\mathbf{n = 8 4 )} \\
\text { Frequency (\%) }\end{array}$ & $\begin{array}{c}\text { Nursing personnel } \\
\text { (n= 62) } \\
\text { Frequency (\%) }\end{array}$ & p-value \\
\hline Avoidance of thoughts or memories of the pandemic & $22(36.7)$ & $21(25)$ & $12(19.4)$ & 0.087 \\
\hline Avoiding conversations on the pandemic & $24(40)$ & $17(20.2)$ & $14(22.6)$ & 0.021 \\
\hline $\begin{array}{l}\text { Avoiding situations, places, or people that cause } \\
\text { recall of the pandemic }\end{array}$ & $17(28.3)$ & $15(17.9)$ & $17(27.4)$ & 0.25 \\
\hline Try not to feel distress or discomfort & $24(40)$ & $27(32.1)$ & $20(32.3)$ & 0.56 \\
\hline
\end{tabular}

ASD: Acute stress disorder

${ }^{*} p$-values calculated by $\chi^{2}$ test.

Table 6. Arousal symptoms (ASD scale) by profession

\begin{tabular}{|c|c|c|c|c|}
\hline Item & $\begin{array}{c}\text { Resident physicians } \\
\text { (n=60) } \\
\text { Frequency (\%) }\end{array}$ & $\begin{array}{l}\text { Attending physicians } \\
\qquad \begin{array}{c}(\mathrm{n}=84) \\
\text { Frequency }(\%)\end{array}\end{array}$ & $\begin{array}{l}\text { Nursing personnel } \\
\qquad(\mathrm{n}=62) \\
\text { Frequency (\%) }\end{array}$ & p-value \\
\hline Difficulty sleeping & $34(56.7)$ & $32(38.1)$ & $30(48.4)$ & 0.084 \\
\hline Increased irritability & $22(36.7)$ & $27(32.1)$ & $19(30.6)$ & 0.76 \\
\hline Difficulty concentrating & $26(43.3)$ & $25(29.8)$ & $15(24.2)$ & 0.065 \\
\hline Increased danger alertness & $27(45)$ & $35(41.7)$ & $34(54.8)$ & 0.27 \\
\hline Increased anxiety or startle response & $28(46.7)$ & $31(36.9)$ & 23(37.1) & 0.43 \\
\hline $\begin{array}{l}\text { Physical reactions when remembering the } \\
\text { pandemic }\end{array}$ & $8(13.3)$ & $9(10.7)$ & $11(17.7)$ & 0.47 \\
\hline
\end{tabular}

ASD: Acute stress disorder.

${ }^{*}$ p-values calculated by $\chi^{2}$ test.

\section{Avoidance symptoms}

The most frequently reported symptom of avoidance by the groups was avoiding emotions such as distress or discomfort. A statistically significant difference was found between the groups in the item avoiding conversations on the subject, reported by $40 \%$ of resident physicians, $20.2 \%$ of attending physicians, and $22.6 \%$ 
of nursing personnel $(p=0.021)$. Although no statistically significant difference was found, we observed a trend in the item of thought avoidance, reported by $36.7 \%$ of resident physicians followed by $25 \%$ of attending physicians and $19.4 \%$ of the nursing personnel $(p=0.087)$ (Table 5).

\section{Arousal symptoms}

The most frequently reported subset of symptoms in all the groups were arousal symptoms. Although no significant differences were detected, a trend was found in the item of difficulty in sleeping, reported by $56.7 \%$ of resident physicians, $38.1 \%$ of attending physicians, and $48.4 \%$ of nursing personnel ( $p=0.084)$. Similarly, difficulty concentrating was reported by $43.3 \%$ of resident physicians, $29.5 \%$ of attending physicians, and $24.2 \%$ of nursing personnel $(p=0.065)$ (Table 6).

\section{Discussion}

This study found that $88.8 \%$ of health care workers met the criteria for suspected ASD. This result is slightly higher than the results of other studies. For example, in a systematic review conducted to understand the impact of epidemics on health care workers' mental health, a prevalence of ASD between $31 \%$ and $82 \%$ was reported ${ }^{9}$. In a study on stress-related disorders during the COVID-19 pandemic, $40 \%$ of health care workers met PTSD criteria, while $97.9 \%$ reported at least one symptom ${ }^{10}$.

Regarding the difference between the prevalence of ASD in health care workers compared to the general population in the context of COVID-19, a study in the Chinese population in Wuhan examined the symptoms of post-traumatic stress in the general population. The authors found that $7 \%$ of the participants presented post-traumatic stress symptoms, most of them associated with $\mathrm{ASD}^{11}$. This figure is considerably lower than that found in studies of the prevalence of ASD in health care workers ${ }^{9,10}$.

When comparing the ASD scale scores between groups, no statistically significant differences in the overall score were found in the present study. However, resident physicians showed the highest scores on each of the symptom subsets.

In Mexico, medical residents' training is a process that can be considered stressful on its own. Residents face long workdays combined with a heavy burden of caregiving and academic activities and decreased sleep and recreational activities. The COVID-19 health emergency has increased the work demand and the need for updating for residents. Moreover, they may also face other stress factors, such as fear of infecting their beloved ones, being away from their families, economic problems, a stigma for dealing with COVID-19 patients, fear of getting infected, and the uncertainty of dealing with a new disease. In a study conducted in Shanghai, some psychopathological symptoms were recorded in 385 first year medical residents. Data collection began in October 2019 and ended in February 2020, when the pandemic peaked in China. Depression scores increased by $61 \%$, while anxiety scores increased by $64 \%{ }^{12}$.

Regarding dissociative symptoms, a statistically significant difference was found in the item of emotional distancing, which was more frequently reported within the groups of resident physicians and nursing personnel. Dissociative symptoms correspond to defense mechanisms that can occur in traumatic situations, which are presented as isolating or separating oneself from the traumatic event to experience less anxiety. Emotional distancing is also present in the burnout syndrome. This syndrome is characterized by emotional exhaustion, depersonalization, and low self-realization in individuals who work for the care or helping others. In medical or paramedical personnel, this syndrome can be more severe since many accidents or iatrogenic events can occur due to the profession's nature. Furthermore, the patients may be treated with less quality and warmth than they deserve, which affects the healing process ${ }^{13}$. It would be worthwhile to investigate the prevalence of burnout in this population, particularly concerning the pandemic's work situation.

Particularly, throughout their training, health care workers are taught that maintaining a certain emotional distance may be necessary to avoid becoming paralyzed by stress, to be functional and objective in a moment of crisis, and to be able to help patients. Furthermore, sometimes, the expression of emotions in medical practice can be perceived as unprofessional, so many health workers learn to suppress and ignore these emotions. Persistent avoidance of emotions can prevent health-care providers from genuinely engaging with patients and their feelings, which is the basis for empathy ${ }^{14}$.

A statistically significant difference was found in the item avoiding conversations on the event; a trend was also found in the item avoiding thinking about the topic. Both items showed a higher frequency in resident physicians. The avoidance symptoms correspond to 
defense mechanisms that keep the traumatic event out of conscious thinking to diminish the anxiety presented when remembering or thinking about them. It has been described that avoidance predicts stress and depression in the future. This coping strategy is most often seen in individuals less acquainted with the proper handling of adversity. In a study of 112 pediatric residents at a tertiary level care pediatric hospital in Mexico, $71.4 \%$ were found to use avoidance strategies ${ }^{15}$.

This study also stands out that arousal symptoms were the most frequently reported symptoms in all the groups. A trend was found in the difficulty of sleep and difficulty concentrating; both symptoms were presented more often in resident physicians. The arousal symptoms refer to a constant feeling of having to be in "fight, flight, paralysis" mode, which is typically part of the healthy response to a threat, while in the case of ASD, this feeling persists even when there is no threat. The manifestations include an exaggerated startle response to minimal stimuli, irritability, sleep disturbances, decreased concentration, or a hypervigilance state. One of the factors that can contribute to these symptoms is that COVID-19 is a new disease. The continuous discoveries on this disease radically change care protocols and cause a sense of uncertainty and the constant expectation of being in front of the unknown ${ }^{16}$.

This article has several strengths and limitations. This study is the first in our country specifically focused on exploring acute stress symptoms in health care workers during the COVID-19 pandemic context. In this sense, one of the study limitations is that most of the responses were obtained during May's $1^{\text {st }}$ week. That is when the pandemic was not yet at its peak in our country, and the Hospital Infantil de México Federico Gómez was not receiving a significant number of cases yet. It would be worthwhile to conduct repeated measurements in this population at different points during the pandemic to have a better point of comparison, then apply an ASD scale and determine how often people who presented ASD developed posttraumatic stress during the COVID-19 pandemic.

Another limitation of the study is that the ASD scale only provides information about whether the participants meet criterion B for diagnosis. Therefore, we cannot assume that people who tested positive on this scale have the disorder's diagnosis. Criterion A is met since the population is directly exposed to a traumatic event (in this case, treating patients with COVID-19); criterion $C$ indicates that the disorder's duration (symptoms of criterion B) should be from 3 days to 1 month after exposure to the event. Considering that the answers were obtained within this period, we believe that this criterion can be met. However, it is not possible to determine if criterion D was met, which tells us that the disturbance causes clinically significant discomfort or impairment in social, occupational, or other important areas of functioning since this factor was not explicitly examined. It is also not possible to determine whether criterion $E$ was met. In this item, the disturbance cannot be attributed to a substance or other medical condition's physiological effects and is not better explained by a brief psychotic disorder. This information could be completed by the follow-up of participants who met criterion B.

Due to the high risk of contagion, another limitation is that the information was obtained from a virtual questionnaire, so there could be various biases. In contrast, answering the virtual questionnaire was easier without exposing people to contagion.

Multiple factors could be related to the frequency of acute stress in these groups. Therefore, it is necessary to investigate the importance of risk and protective factors present in this population and explore other psychopathologies such as depression or substance abuse.

More than half of the health care workers at a tertiary level pediatric hospital experienced ASD during the COVID-19 National Safe Distance Strategy. There are different factors related to the type of work that health care workers perform, which can be associated with acute stress symptoms. Further research should be conducted on this population to develop strategies to reduce the risk of ASD within and outside the pandemic context.

\section{Ethical disclosures}

Protection of human and animal subjects. The authors declare that no experiments were performed on humans or animals for this study.

Confidentiality of data. The authors declare that they have followed the protocols of their work center on patient data publication.

Right to privacy and informed consent. The authors have obtained the written informed consent of the patients or subjects mentioned in the article. The corresponding author has this document. This study was authorized by the Bioethics Committee (registration HIM-2020-006).

\section{Conflicts of interest}

The authors declare no conflicts of interest. 


\section{G.C. Chapa-Koloffon, et al.: Acute stress in health care workers during the safe distance intervention}

\section{Funding}

No funding was received.

\section{References}

1. Xu Z, Shi L, Wang Y, Zhang J, Huang L, Zhang C, et al. Pathological findings of COVID-19 associated with acute respiratory distress syndrome. Lancet Respir Med. 2020;8:420-2.

2. Wu F, Zhao S, Yu B, Chen YM, Wang W, Song ZG, et al. A new coronavirus associated with human respiratory disease in China. Nature. 2020;579:265-9

3. Organización Mundial de la Salud. ¿Qué es una pandemia? Available from: https://www.who.int/csr/disease/swineflu/frequently_asked_questions/pandemic/es.

4. Gobierno de México. Presidencia. Versión Estenográfica. Conferencia de Prensa. Informe Diario Sobre Coronavirus COVID-19 en México. Available from: https://www.gob.mx/presidencia/articulos/version-estenografica-conferencia-de-prensa-informe-diario-sobre-coronavirus-covid-19-en-mexico-239175

5. Shultz JM, Baingana F, Neria Y. The 2014 Ebola outbreak and mental health: current status and recommended response. JAMA. 2015;313:567-8.

6. American Psychiatric Association. DSM-5 diagnostic classification. In Diagnostic and Statistical Manual of Mental Disorders. Washington, DC American Psychiatric Association; 2013.

7. Fisterra Guías Clínicas. Quintero J. Diagnóstico y Manejo del Trastorno Por Estrés Postraumático. Madrid: Fisterra; 2015. Available from: https:/ www.fisterra.com/guias-clinicas/diagnostico-manejo-trastorno-por-estres-postraumatico.
8. Durón FR, Cárdenas LG, De la Rosa GA. Estructura factorial de la Escala de Trastorno por Estrés Agudo en población mexicana. JBHSI. 2018;10:7-

9. Ricci-Cabello I, Meneses-Echavez JF, Serrano-Ripollo MJ, Fraile-Navarro D, Fiol de Roque MA, Pastor-Moreno G, et al. Impact of viral epidemic outbreaks on mental health of healthcare workers: a rapid systematic review. medRxiv. 2020. Preprint (not peer reviewed). doi: 10.1101/2020.04.02.20048892.

10. Si M, Su XY, Jiang Y, Wang WJ, Gu XF, Ma L, et al. The psychological impact of COVID-19 on medical care workers in China. Infect Dis Poverty. 2020;9:113.

11. Liu N, Zhang F, Wei C, Jia Y, Shang Z, Sun L, et al. Prevalence and predictors of PTSS during COVID-19 outbreak in China hardest-hit areas: gender differences matter. Psychiatry Res. 2020;287:112921.

12. Li W, Frank E, Zhao Z, Chen L, Wang Z, Burmeister M, et al. Mental health of young physicians in China during the novel coronavirus disease 2019 outbreak. JAMA Netw Open. 2020;3:e2010705.

13. Velásquez-Pérez L, Colin-Piana R, González-González M. Afrontando la residencia médica: depresión y burnout. Gac Med Mex. 2013;149:183-95

14. Kerasidou A, Horn R. Making space for empathy: supporting doctors in the emotional labour of clinical care. BMC Med Ethics. $2016 ; 17: 1-5$

15. Sepúlveda-Vildósola A, Romero-Guerra A, Jaramillo-Villanueva L. Estrategias de afrontamiento y su relación con depresión y ansiedad en residentes de pediatría en un hospital de tercer nivel. Bol Med Hosp Infant Mex. 2012;69:347-54.

16. Horesh D, Brown AD. Traumatic stress in the age of COVID-19: a call to close critical gaps and adapt to new realities. Psychol Trauma. 2020;12:331-5. 